\title{
Assessment of Undergraduate Business Education Students Usage of Social Networking as a Platform for Entrepreneurship Activities in North-West, Nigeria
}

\author{
${ }^{1}$ Abubakar Mahmud, ${ }^{2}$ Adamu Ibrahim*, ${ }^{3}$ Hamza Ismaila \\ Email : adamugadabs@gmail.com * \\ *: coresponding author \\ 1,2,3 Department of Vocational and Technology Education, Abubakar Tafawa Balewa University Bauchi, \\ ,Bauchi State, Nigeria
}

Article history

Received Okt 20, 2021

Revised Nov 26, 2021

Accepted Nov 30, 2021

Keywords

Undergraduate

Usage

Social Networking

Platform

Entrepreneurship

Activities
The study assessed the undergraduate business education students' usage of social networking as a platform for entrepreneurship activities in North-west, Nigeria. Specifically, the study had five objectives, five research questions and five null hypotheses. The study anchored theory of Technology Acceptance Model of Ajzen and Fishbein's, (1980) and Division of Innovation Theory (DOI) of Rogers (1995). The study adopted a survey research design. The population of this study comprises of all the 407 final undergraduate business education 2019/2020 academic session in North-west Nigeria. The entire population was used for the study. The instrument for the data collection was a structured questionnaire. The instrument was validated by four experts, pilot tested and a reliability coefficient of 0.81 was obtained. The data were collected by the researcher assisted by four research assistants using personal contact method. Descriptive statistics of mean and standard deviation was employed to answer the research questions. The hypotheses were tested using Analysis of Variance (ANOVA) at the 0.05 level of significance. The results revealed among others that the level of students' awareness, perceived ease of use and perceived usefulness of social networking as a platform for entrepreneurship activities in tertiary institutions in Northwest Nigeria was low. Based on these, it was concluded that the business education will not reap the benefit of social networking sites to searcher for business opportunities, venture into business and meet the needs of their technologically savvy customers. It was recommended among others that business education lecturers should create awareness on students on the role of social networking as a platform for entrepreneurship activities.

This is an open access article under the CC-BY-SA license.

\section{Introduction}

Social networking sites (SNSs), otherwise known as social media, is an online platform that focuses on building social relations among people, who share interests, background or activities. Social 
networking is a digital system where people connect to each other using internet service (Weber, (2009). Accordingly, Examples of social networks include Facebook, WhatsApp, Twitter, Instagram, Blackberry Messenger, YouTube, Live!. Skype. Google+. Yahoo! Messenger, WhatsApp. 2go, and many others (Computer Weekly, 2015). With the help of Internet all the social site and various applications users can converse and interact with each other.

Globally, Social networking has bulldozed the communication barriers. The use of social media is growing among populace and opened up a whole new world of social interaction. With the aid of networking technology, more information becomes available to the public through a wide range of channels which the users can access online information Kim, YooLee \& Sin, (2011). It is now possible for people to make interpersonal communication with others and access information as quickly as possible through the use of social media (Karr, 2015). Sokoya, Onifade and Alabi (2012) opined that Social media is popular because it allows people to connect in the online world to form a group, a forum and community where ideas and information can be exchanged without geographic barrier. This explained why Social networks have become popular channel of education, personal, political and business and communication in $21^{\text {st }}$ technological era.

Building on the above, there is no doubt that Social networks sites are a critical asset that enables better access, depth and reach of an entrepreneur's opportunity identification and resource acquisition network online for business activities. In this regard, empirical evidences have shown that the use of the SNSs for business activities have tremendous advantage. Fischer et al. (2011) suggested that the use of SNSs offers new effectual pathways whereby new insights and resources can emerge for entrepreneurial individuals. More so, Nasir, Nawi, Mamun, Fazal and Raston (2017) point out that SNS websites have gained remarkable recognition among Internet users and have become a fundamental part of customers' behaviour and everyday life. Additionally, the rapid growth of Social Networking has transformed business activities such as marketing, advertising, promotion, brand creation, and development, including as distribution channels (Hanna et al., 2011). In their view, Seroka-Stolka and Tomski (2014) opined that SNSs utilization provides powerful tools that enable nascent entrepreneurs to reach out to not only national but also foreign contacts and to gather the required information easily. Further more, Nasir et al. (2017) opined that the recognized power of social networking sites on business activities and its applications, many nascent and young entrepreneurs and students use these website tools to operate their new businesses and spread their messages or test their products in new markets.

Looking at the foregoing, it is evidently clear to note that there is no gain saying implementation of the social media in the business sector has helped to improves worthiness, 
cultivate strategic partnerships and enhance their contact with suppliers and clients. In line with this, Zahra (2011) opined that social media offers a platform where it allows business and entrepreneurs to communicate rapidly and economically with clients as well as it also allows them to build a database that can be used to generate business leads that may translate to enhanced the sales and results growth of the business. This shows that the prologue of the social media has become the means whereby every business owners as well as entrepreneurs want to grab the advantage to generate value for their business and entrepreneurship (Kirakosyan, 2014).

Despite the aforementioned advantages of social networking sites on business activities, no existing literature on undergraduate business education students' usage of social networking sites as a platform for entrepreneurship activities in North-west Nigeria. Oxnevad (2013) reported that most tertiary institutions students use social media for charting and watching videos, but lacks basic skills for generating online materials for their assignment and collaborating learning. Ajayi (2015) stated that most students waste their time using social media for charting downloading and watching videos without knowing its impact on income generation. Considering that the usage of social networking sites for entrepreneurship activities among undergraduate business education students is still rarity in studies at the present times urged the researcher to: (1) determine the level of awareness on the use of social networking as a platform for entrepreneurship activities; (2) determine the perceived ease of use of social networking as a platform for entrepreneurship activities; (3) determine the perceived usefulness of social networking as a platform for entrepreneurship activities; (4) determine the extent to which undergraduate business education students' adoption of social networking as a platform for entrepreneurship activities; and (5) determine the extent to which undergraduate business education students' utilize social networking as a platform for entrepreneurship activities in North-west, Nigeria

\section{Research Questions.}

In line with the specific objectives the following research questions guided the study:

1. What is the level of undergraduate business education students' awareness of social networking as a platform for entrepreneurship activities?

2. What is the perceived ease of use of social networking as a platform for entrepreneurship activities.?

3. What is the perceived usefulness of social networking as a platform for entrepreneurship activities?

4. To what extent undergraduate business education students' adoption of social networking as a platform for entrepreneurship activities?

5. To what extent undergraduate business education students' utilize social networking as a 
platform for entrepreneurship activities?

\section{Hypotheses}

The following null hypotheses were using ANOVA at 5\% level of significance:

$\mathbf{H O}_{1}$ There is no significance difference among the mean responses of undergraduate business education students based on their institutions on their awareness on the use of social networking as a platform for entrepreneurship activities.

$\mathbf{H O}_{2}$ There is no significance difference among the mean responses of undergraduate students based on their institutions on perceived ease of use of social networking as a platform for entrepreneurship activities.

$\mathbf{H O}_{3}$ There is no significance difference among the mean responses of undergraduate business education students based on their institutions on perceived usefulness of social networking as a platform for entrepreneurship activities.

$\mathbf{H O}_{4}$ There is no significance difference among the mean responses of undergraduate business education students based on their institutions on adoption of social networking as a platform for entrepreneurship activities.

$\mathbf{H O}_{5}$ There is no significance difference among the mean responses of undergraduate business education students based on their institutions on utilization social networking as a platform for entrepreneurship activities.

\section{Method}

\section{Research Design}

The study adopted a descriptive survey. According to Fisher (2011), a descriptive survey should be employed when a study sought to determine the opinions, feelings, and thoughts of the respondents about a particular situation. In this study, the researchers to collect and analyze quantitative data as well as suggesting the reasons for the relationship between the variables of interest (Saunders 2009); hence the design was considered appropriate for achieving the objectives of this study.

\section{Population and Sample for the Study}

The target population of this study comprises of all the 407 final year students in the five tertiary institutions that offered undergraduate programme in business education in 2019/2020 academic session in north western Nigeria. The population of the study was manageable; hence the entire 407 students were used for the study. This is in agreement with the decision of Glenn (2009) who suggested that at Precision level of $\pm 3 \%$, for population of $\leq 1,000$, the entire population should be used. Douglass (2006) assert that sample size has to be enough, to enable a researcher detect similarities and differences among variables. Based on the forgone argument, the Total Population Sample was used for the study. 


\section{Instrument for Data Collection}

As recommended by Churchill (1979) that a researcher can adopt or adapt from the prior studies relevant to the current research. The instrument for the data collection was adapted questionnaire from Nasir et al. (2017) titled Social Networking Sites for Business Activities (SNSBA). The questionnaire was structured in 4 points rating scale with the values of High Extent $(\mathrm{HE})=4$ points, Moderate Extent $(\mathrm{ME})=3$ points, Low Extent $(\mathrm{LE})=2$ points, and Very Low Extent $(\mathrm{VLE})=1$ point

Each of the four-construct based on the value objectives has 10 questionnaire items.

\section{Validation of Instrument}

The instrument for data collections was validated by 4 experts. The experts checked and evaluate both content and structure of the instrument in relation to the objectives of the study. Their inputs were incorporated into the final copy of the instrument.

\section{Reliability of Research Instrument}

Pilot study was conducted at Abubakar Tafawa Balewa University, Bauchi which is outside the study area but has common characteristics with the area of the study. Data collected from pilot study were coded into Statistical Package of Social Science (SPSS) version 23. The package was used to run Cronbach reliability test. Madiha and Walid (2016) suggested that Cronbach's alpha should be used to measure the internal consistency of the questions in a questionnaire in which reliability coefficient of 0.81 was obtained. The instrument was considered reliable based on Madiha and Walid (2016) who opined that if a coefficient is greater than or equal to 0.7 , the instrument should be considered significant and reliable for the study.

\section{Method of Data Collection}

Data were collected by the researcher with the aid of four (4) trained research assistants using face to face delivery approach. Respondents were given time to complete the instrument. The approach enabled the researchers to have high rate of return of completed questionnaire. The exercise lasted for 3 weeks.

\section{Method of Data Analysis}

The data collected were The data collected were coded into Statistical Package of Social Sciences (SPSS) version 23. The package was used to run descriptive statistical of mean and standard deviation were employed to answer the research questions. In answering research questions, interval scale of $0.00-0.99$ (very low extent), $1.00-1.99$ (low extent), $2.00-2.99$ (moderate extent) and $3.00-4.00$ (high extent) adopted from Adamu and Mukthar (2018) will be use as decision rule. 
The Analysis of Variance (ANOVA) in the test of the null hypotheses at 5\% level of significance. The reason for choosing ANOVA to test the Five null hypotheses is based on the assertion of De Coster etal (2006) who stated that the most common way to determine whether there are differences in the means of a continuous Dependent Variables (DV) across a set of three or more groups is to perform analysis of variance (ANOVA). In the analysis, where $P \leq \alpha$, the null hypothesis was rejected and on the other hand where $P \geq \alpha$, the null hypothesis was retained.

\section{Result and Discussion}

The results of research questions are as presented in Table 2 to Table 6

\section{Research Question One}

What is the level of undergraduate business education students' awareness of social networking as a platform for entrepreneurship activities?

The analysis of data that answer research question one in Table 2 revealed that the mean scores ranged 2.08 (LE) 2.65 (ME) with standard deviations of 0.52 and 0.66 respectively. The grand mean of 2.39 obtained suggested that the level of business education students' awareness of social networking as a platform for entrepreneurship activities was low.

Table 2: Descriptive statistics of respondents on their awareness of social networking as a platform for entrepreneurship activities

\begin{tabular}{|c|c|c|c|c|}
\hline S/no & Questionnaire statement & MA & Std.div & Remark \\
\hline 1. & $\begin{array}{l}\text { The extent of my awareness of the use of Social } \\
\text { networking platforms for improving products, sale and } \\
\text { services is }\end{array}$ & 2.25 & 0.56 & LE \\
\hline 2. & $\begin{array}{l}\text { The extent to which I have the knowledge on the use of } \\
\text { Social networking platforms for entrepreneurship is }\end{array}$ & 2.60 & 0.65 & ME \\
\hline 3. & $\begin{array}{l}\text { The extent of my knowledge on the use of Social } \\
\text { networking platforms in making decisions on new } \\
\text { products is }\end{array}$ & 2.23 & 0.56 & LE \\
\hline 4. & $\begin{array}{l}\text { The extent of my awareness of the use of Social } \\
\text { networking platforms for dissemination and sharing of } \\
\text { information to target customers }\end{array}$ & 2.49 & 0.62 & LE \\
\hline 5. & $\begin{array}{l}\text { The extent of my awareness of the use of Social } \\
\text { networking platforms to determine marketing } \\
\text { opportunity is }\end{array}$ & 2.35 & 0.59 & LE \\
\hline
\end{tabular}


6. The extent of my awareness on the use of Social $2.65 \quad 0.66$ ME networking platforms for collaborating with business organisation is

7. My knowledge of Social networking platforms to discover business opportunities is

8. The extent of my awareness of the use of Social networking platforms for creating virtual business transactions is

9. The extent of my awareness of the use of Social networking platform to provide easy access between buyers and sellers is

10. The extent of my awareness of the Social networking platforms to create opportunities to search for information on products and to make comparison is

\section{Grand Mean}

Source: Fieldwork, 2020

\section{Research Question Two}

What is the perceived ease of use of social networking as a platform for entrepreneurship activities among undergraduate business education students in North-west, Nigeria?

The descriptive statistics of 10 questionnaire items used to answer research question two revealed the mean ranged 2.26 (LE) to 2.67 (ME). The grand mean of the 10 items obtained was 2.44. The obtained mean suggested that the perceived ease of use of social networking as a platform for entrepreneurship activities among undergraduate business education students in North-west, Nigeria was low.

Table 3: Descriptive statistics of respondents on perceived ease use of social networking as a platform for entrepreneurship activities

\begin{tabular}{llccc}
\hline S/no & \multicolumn{1}{c}{ Questionnaire statement } & MA & $\begin{array}{c}\text { Std.d } \\
\text { iv }\end{array}$ & $\begin{array}{c}\text { Rem } \\
\text { ark }\end{array}$ \\
\hline 11. & $\begin{array}{l}\text { The extent of my skills on using social networking sites } \\
\text { tracking on business activities }\end{array}$ & 2.34 & 0.59 & LE \\
12. $\quad \begin{array}{l}\text { The extent I can manipulate social networking sites tracking } \\
\text { business activities is }\end{array}$ & 2.39 & 0.60 & LE
\end{tabular}


13. The extent I can interact with social networking sites tracking

$2.48 \quad 0.62 \quad$ LE business activities is

14. The extent of my flexibility on the use of social networking

$2.37 \quad 0.59 \quad$ LE sites negotiating business activities is

15. My skills on the use of social networking sites settling for $2.64 \quad 0.66 \quad \mathrm{ME}$ goods bought is

16. The extent of my skills for business activities is $2.35 \quad 0.59 \quad$ LE

17. The extent of my skills on the use of social networking sites $2.55 \quad 0.64 \quad$ ME for bargaining is

18. The extent I operate and understandable for business $2.26 \quad 0.56 \quad$ LE activities is.

19. The extent to which social networking can be used for business activities is more flexible than traditional one.

20. My skills on operating social networking for business is $2.35 \quad 0.59 \quad$ LE Grand Mean

Source: Fieldwork, 2020

\section{Research Question Three}

What is the perceived usefulness of social networking as a platform for entrepreneurship activities among undergraduate business education students in North-west, Nigeria?

The result of research question three presented in Table 4 revealed the highest mean score of 2.81 and the lowest was 2.22 with standard deviations of 0.70 and 0.56 . The grand mean obtained was 2.45, the mean obtained suggested that the perceived usefulness of social networking as a platform for entrepreneurship activities among undergraduate business education students in North-west, Nigeria was low.

$\backslash$ Table 4: Descriptive statistics of respondents on perceived usefulness of social networking as a platform for entrepreneurship activities

\begin{tabular}{llccc}
\hline S/no & \multicolumn{1}{c}{ Questionnaire statement } & MA & Std.div & Remark \\
\hline 21. & $\begin{array}{l}\text { The positive influence of social net working for business } \\
\text { transactions is }\end{array}$ & 0.60 & LE \\
22. $\quad \begin{array}{l}\text { The value of using social net working for business } \\
\text { activities is }\end{array}$ & 2.27 & 0.57 & LE \\
\hline
\end{tabular}


23. The trends of using social net working for business 2.6

$0.65 \quad \mathrm{ME}$ transaction is

24. The extent to which I am satisfied using social networking 2.40

$0.60 \quad$ LE sites for business activities is

25. The level of my confident in using the social networking 2.58 sites tracking business activities

26. The extent to which I share information about business activities using social networking sites is

27. My ability to accomplish business activities quickly using 2.22 social networking sites is

28. The extent of usefulness of social networking on buying and selling is

29. The extent to which social networking sites enhances the business activities is

30. The extent to which social networking sites attracts 2.81 consumers when using advertisement media is

\section{Grand Mean}

Source: Fieldwork, 2020

\section{Research Question Four}

To what extent do undergraduate business education students' adoption of social networking as a platform for entrepreneurship activities in North-west, Nigeria?

The result used to answer the research question four revealed the weighted mean scores ranged 2.22 to 2.53 representing low extent and moderate extent respectively. The grand mean obtained of 2.39 found to be under the index score of low extent. It was conducted that the extent to which undergraduate business education students' adoption of social networking as a platform for entrepreneurship activities in North-west, Nigeria was low.

Table 5: Descriptive statistics of respondents on adoption of social networking as a platform for entrepreneurship activities

\begin{tabular}{llccc}
\hline S/no & \multicolumn{1}{c}{ Questionnaire statement } & MA & Std.div & Remark \\
\hline 31. & $\begin{array}{l}\text { The extent of adoption of Social networking platforms in } \\
\text { discovering entrepreneurship activities. }\end{array}$ & 2.44 & 0.61 & LE \\
& & & &
\end{tabular}


32. The extent of adoption of Social networking platforms for $\begin{array}{llll}2.53 & 0.63 & \text { LE }\end{array}$ understanding markets trends and changes.

33. The extent to which social networking platforms is adopted

$2.33 \quad 0.58 \quad$ LE to recognize changes in technology, markets and concept is

34. The extent to which Social networking platforms are $2.39 \quad 0.60 \quad$ LE adopted in comprehending customer problem is

35. The adoption of Social networking platforms are used in $\begin{array}{llll}2.44 & 0.61 & \text { LE }\end{array}$ discovering drawback on products or services is

36. The extent of adoption of Social networking platforms for $\begin{array}{llll}2.27 & 0.57 \quad \text { LE }\end{array}$ loading and uploading information on goods and services.

37. The extent to which Social networking platforms are used in $\begin{array}{lll}2.22 & 0.55 & \text { LE }\end{array}$ obtaining work related information is

38. The extent of adoption of Social networking platforms to $2.29 \quad 0.57 \quad$ LE recognize changes in marketing competitions is

39. The extent to which Social networking platforms are $2.50 \quad 0.62 \quad \mathrm{ME}$ adopted in comprehending markets characteristics and ways to serve the markets is

40. The extent to which Social networking platforms are $2.53 \quad 0.63 \quad \mathrm{ME}$ adopted in gathering

Customer feedback and information.

\section{Grand Mean}

$2.39 \quad 0.60$

LE

Source: Fieldwork, 2020

\section{Research Question Five}

To what extent do undergraduate business education students' utilize social networking as a platform for entrepreneurship activities in North-west, Nigeria?

The analysis of the 10 questionnaire items used to address research question five revealed the mean scores ranged 2.08 (LE) to 2.64 (ME). The grand mean of 2.41 obtained indicated that the extent to which undergraduate business education students' utilize social networking as a platform for entrepreneurship activities in North-west, Nigeria was low. This suggested that occasional used social networking sites for entrepreneurship activities.

Table 6 Descriptive statistics of respondents on utilization of social networking as a platform for entrepreneurship activities 


\begin{tabular}{|c|c|c|c|c|}
\hline S/no & Questionnaire statement & MA & Std.div & Remark \\
\hline 41. & $\begin{array}{l}\text { To what extent social networking sites is easy to interact } \\
\text { business activities }\end{array}$ & 2.08 & 0.52 & LE \\
\hline 42. & $\begin{array}{l}\text { The extent to which I utilize social networking sites for } \\
\text { business activities is }\end{array}$ & 2.61 & 0.65 & ME \\
\hline 43. & $\begin{array}{l}\text { The extent I use using social net working sites for } \\
\text { business }\end{array}$ & 2.62 & 0.65 & ME \\
\hline 44. & $\begin{array}{l}\text { The extent I found the various functions of social } \\
\text { networking sites for business integrate }\end{array}$ & 2.58 & 0.64 & ME \\
\hline 45. & $\begin{array}{l}\text { The extent to which I think that I would like to use social } \\
\text { networking sites for business activities }\end{array}$ & 2.24 & 0.56 & LE \\
\hline 46. & $\begin{array}{l}\text { The extent to which I use social networking sites paying } \\
\text { for debts and services is }\end{array}$ & 2.33 & 0.58 & LE \\
\hline 47. & $\begin{array}{l}\text { The extent to which I found social networking sites } \\
\text { accurate of business transactions is }\end{array}$ & 2.22 & 0.56 & LE \\
\hline 48. & $\begin{array}{l}\text { My adoption of social networking sites enable me to use it } \\
\text { of business activities }\end{array}$ & 2.46 & 0.61 & LE \\
\hline 49. & $\begin{array}{l}\text { The extent to which I do use social networking sites for } \\
\text { business activities is }\end{array}$ & 2.26 & 0.56 & LE \\
\hline 50. & $\begin{array}{l}\text { The extent to which I derived pleasure on using social } \\
\text { networking sites for business is }\end{array}$ & 2.64 & 0.66 & $\mathrm{ME}$ \\
\hline & Grand mean & 2.41 & 0.60 & LE \\
\hline
\end{tabular}

Source: Fieldwork, 2020

\section{Results of Hypotheses}

The results of test of null hypotheses was as presented in Tables 7 to 11.

\section{Research Hypothesis One}

There is no significance difference among mean responses of undergraduate business education students based on their institutions on their awareness on the use of social networking as a platform for entrepreneurship activities in North-west, Nigeria. 
The output of analysis of variance used to test null hypothesis one in Table 7 revealed that the $\mathrm{F}(2, .496)$ value of .669 and the $p=.513$. The $p$-value obtained was greater than the level of significance $(.513>0.05)$. The result indicated that there was no significance difference among mean responses of the students the use of social networking as a platform for entrepreneurship activities in North-west, Nigeria. The hypothesis was retained.

Table 7: Analysis of Variance on the test difference among mean responses of students based on their institutions on their awareness on the use of social networking as a platform for entrepreneurship activities

\begin{tabular}{lcrccc}
\hline & Sum of Squares & Df & Mean Square & F & Sig. \\
\hline Between Groups & 2.48 & 5 & .496 & .669 & .513 \\
Within Groups & 240.408 & 324 & .742 & & \\
Total & 242.888 & 329 & & & \\
\hline
\end{tabular}

\section{Research Hypothesis Two}

There is no significance difference among mean responses of undergraduate students based on their institutions on perceived ease of use of social networking as a platform for entrepreneurship activities in North-west, Nigeria.

The $\mathrm{F}(2, .688)$ value of .936 was obtained from analysis of variance used to test null hypothesis two and the $p=.394$. From Table 8 , the $p$-value of .394 obtained was found to be greater than the 0.05 level of significance. The result indicated that no statistical difference exists among the mean responses of the students on perceived ease of use of social networking as a platform for entrepreneurship activities in North-west, Nigeria. The hypothesis was retained.

Table 8: Analysis of Variance on the test difference among mean responses of students based on their institutions on perceived ease of use of social networking as a platform for entrepreneurship activities

\begin{tabular}{lcrccc}
\hline & Sum of Squares & Df & Mean Square & F & Sig. \\
\hline Between Groups & 3.44 & 5 & .688 & .936 & .394 \\
Within Groups & 238.14 & 324 & .735 & & \\
Total & 241.58 & 329 & & & \\
\hline
\end{tabular}

\section{Research Hypothesis Three}

There is no significance difference among mean responses of undergraduate business education students based on their institutions on perceived usefulness of social networking as a platform for entrepreneurship activities in North-west, Nigeria.

The value of $F(2,173)$ for the data used to test of null hypothesis three revealed was 231 and the p-value stood at .794 at the 0.05 level of significance as seen in Table 9. The p-value obtained was greater than the alpha value $(.794>0.05)$. The obtained $p$-value indicated that no 
significance difference among mean responses of the students on perceived usefulness of social networking as a platform for entrepreneurship activities. The hypothesis was upheld.

Table 9: Analysis of Variance on the test difference among mean responses of students based on their institutions on perceived usefulness of social networking as a platform for entrepreneurship activities

\begin{tabular}{lrrrrr}
\hline & Sum of Squares & Df & Mean Square & F & Sig. \\
\hline Between Groups & .865 & 5 & .173 & .231 & .794 \\
Within Groups & 243.00 & 324 & .750 & & \\
Total & $243 . .865$ & 329 & & & \\
\hline
\end{tabular}

\section{Research Hypothesis Four}

There is no significance difference among mean responses of undergraduate business education students based on their institutions on adoption of social networking as a platform for entrepreneurship activities in North-west, Nigeria.

The result of test of null hypothesis four in Table 10 revealed the $F(2, .277)=.381$ and the $p=.683$. The $\mathrm{p}$-value of .683 obtained was greater than the alpha value of 0.05 . The obtained $\mathrm{p}$ value suggested that there was no significance difference among mean responses of the students on adoption of social networking as a platform for entrepreneurship activities. The hypothesis was retained.

Table 10: Analysis of Variance on the test difference among mean responses of students based on their institutions on adoption of social networking as a platform for entrepreneurship activities

\begin{tabular}{lcrccc}
\hline & Sum of Squares & Df & Mean Square & F & Sig. \\
\hline Between Groups & 1.385 & 5 & .277 & .381 & .683 \\
Within Groups & 235.87 & 324 & .728 & & \\
Total & 237.26 & 329 & & & \\
\hline
\end{tabular}

\section{Research Hypothesis Five}

There is no significance difference among the mean responses of undergraduate business education students based on their institutions on utilization social networking as a platform for entrepreneurship activities in North-west, Nigeria.

The analysis of variance in Table 11 which was used to test null hypothesis five indicated the $\mathrm{F}(2, .548)$ of .759 and the $p=.469$. The $\mathrm{p}$-value (.469) obtained was greater than the alpha value 
(0.05). The result shows that no significant difference exists among the mean responses of the five groups of students on utilization social networking as a platform for entrepreneurship activities. The hypothesis was retained.

Table 11: Analysis of Variance on the test difference among mean responses of students based on their institutions on utilization of social networking as a platform for entrepreneurship activities

\begin{tabular}{lccccc}
\hline & Sum of Squares & Df & Mean Square & F & Sig. \\
\hline Between Groups & 2.74 & 5 & .548 & .759 & .469 \\
Within Groups & 234.25 & 324 & .723 & & \\
Total & 236.99 & 329 & & & \\
\hline
\end{tabular}

\section{Discussion of the Findings}

The result of research question one revealed that level of undergraduate business education students' awareness of social networking as a platform for entrepreneurship activities was low. The test of corresponding null hypothesis indicated that there was no significant difference among the students. The result was found to be similar with the study conducted by Ambrose and Catherine (2013), Jagongo and Kinyua (2013) who reported that the proper understanding of social media tools for entrepreneurship activities has yet to be fully achieved its goal in developing countries. Similarly, Ezenwafor and Onokpaunu (2017) shows that entrepreneurs utilize social media platforms in creating new product image and awareness, marketing new business ideas, stimulating sales of new business products and building long term relationships with their customers at a very low extent in Delta State.

The results of research question two revealed that the perceived ease of use of social networking as a platform for entrepreneurship activities among undergraduate business education students in North-west, Nigeria was low. The test of null hypothesis two further affirmed that there was no significant difference among the mean responses of the students. The outcome of the study agreed with the earlier submission Castañeda et al. (2007) whose studyd indicated that the ease of use of technology is attributed to self-efficacy and instrumentality. . Similarly, Abubakar and Ahmed (2013) reveal that high-level SNS use is influenced by attitudinal, normative, and self-identity factors. Furthermore, this effect has been amply demonstrated in empirical studies about adoption of new technologies. The author added that, business owners rarely possess all the skills and knowledge needed to expand their enterprise, and finding people with the necessary skills, and getting them to contribute, is a vital aspect of their networking. 
The research question three indicated that the perceived usefulness of social networking as a platform for entrepreneurship activities among undergraduate business education students in North-west, Nigeria was low. The test of corresponding null hypothesis suggested that there was no significant difference among the mean responses of the students. The result of the study was found to be in line with that of Cho \& Sagynov (2015) and Hughes (2016) who reported that the perceived competitive usefulness of social networks sites seems to be a pull factor for entrepreneurial intention to gain market share for nascent entrepreneurs. In contrast to previous research, such as Lorenzo-Romero et al. (2013) and Hughes (2016), this research suggests that negative perceptions of trust in SNS' and competitive pressure are serious impediments to foster students' entrepreneurial intention.

The result of research question four which was affirmed by test of null hypothesis four shows that the extent to which the adoption of social networking as a platform for entrepreneurship activities among business education students in North-west, Nigeria was low. The finding was consistent with previous IT adoption research such Shen (2008), Stern et al. (2008) and as Mahapatra (2016). Similarly Hughes (2016) reported that, adopting of social media for entrepreneurial activities was low. The author maintained that the perceived competitive usefulness influenced the intention to adopt social media. However Hughes (2016) attributed the low intention to adopt social media as platform for entrepreneurial activities among youths in United State to low Entrepreneurial Orientation. The author maintained that strong entrepreneurial orientation has positive influence on adoption of SNS for entrepreneurial activities.

The result of research question five and test of corresponding null hypothesis shows that the extent to which undergraduate business education students' utilize social networking as a platform for entrepreneurship activities in North-west, Nigeria was low. The result agreed with Jagongo and Kinyua (2013) whose study shows that most entrepreneurs do not optimally utilize social media platforms because they have not fully understood the potentials for their businesses. The low extent of utilization social media platforms by entrepreneurs in their entrepreneurial activities was also reported by Ukpere, Slabbert and Ukpere (2014) who stated that Nigerian entrepreneurs utilize social media platforms only in corporate and social world but not as a tool for entrepreneurship because of issues of trust and confidentiality. Tthe study Ezenwafor and Onokpaunu (2017) also affirmed that the extent of utilization of social media platforms for entrepreneurial activities is low in Delta state.

Contrary to the finding of this study, the study conducted by Green (2011) shows that most business entrepreneurs have embraced Facebook, LinkedIn and Twitter because it helps them in building their brand and product awareness. It also agrees with Jagongo and Kinyua (2013) who 
maintained that only few social media platforms were highly utilized due to limitations emanating from technical capabilities and infrastructure. In same light, Ajayi (2015) asserted that agroentrepreneurs in Nigeria relatively utilize social networking tools such as Facebook for customer relationship management. The divergent opinions may be attributed to the target respondents used in the study.

\section{Conclusion}

Based on the results of the study, it was concluded that business education students are not fully utilizing the advantage of social networking sites which is the global platform that crave the major players in today's competitive and technologically advanced business environment. It was concluded that business education will have difficulty of reaping the advantage of social networking sites to searcher for business opportunities, venture into business and meet the needs of their technologically savvy customers.

\section{References}

Abubakar, F. M., \& Ahmed, H. (2013). The moderating effect of technology awareness on the relationship between UTAUT constructs and behavioral intention to use technology: A conceptual paper. Australian Journal of Business and Management Research, 3(2), 14-23.

Jagongo and Kinyua (2013) Social Media and the Enterprenueurial Growth( A New Business Communication Paradigm among SMEs in nairobi). Cambridge University Press South Africa.

Ajayi, J.0 (2015). Use and use intensity of social media networking systems by nigerian agroentrepreneurs. Scientific Papers Series Management, Economic Engineering in Agriculture and Rural Development, 15(1), 19 - 26

Ambrose, J. and Kinyua, C. (2013). The Social Media and Entrepreneurship Growth (A New Business Communication Paradigm among SMEs in Nairobi, International Journal of Humanities and Social Science, 3 (10), 213-227

Castañeda, J.A., Muñoz-Leiva, F., Luque, T. (2007). Web Acceptance Model (WAM): Moderating effects of user experience. Information \& Management 44, 384-396.

Cho, Y.C., \& Sagynov, E. (2015). Exploring factors that affect usefulness, ease of use, trust,and purchase intention in the online environment. International Journal of Management \& Information Systems, 19(1), 21.

Churchill, G. A. (1979).A paradigm for developing better measures of marketing constructs. Journal of Marketing Research, XVI, 64-73.

De Coster, C., Quan, H., Finlayson, A. et al. (2006) Identifying priorities in methodological research using ICD-9-CM and ICD-10 administrative data: report from an international consortium. BMC Health Serv Res 6, 77, doi:10.1186/1472-6963-6-77.

Douglass, Y. (2006), Principles of determining Sample in Educational Research. Unpublished reading materials in ResearchAdamu, I. \& Mukthar Y. A. (2018). Appraisal of Business Pedagogical Content Knowledge (BPACK) Competencies Needs for Implementing 
Salesmanship Curriculum in Secondary Schools In Nigeria. Multidisciplinary Journal of Science Technology and Vocational Education, 6 (1), 144- 152

Ezenwafor, J. I. and Onokpaunu M. O. (2017).Utilization of Social Media Platforms by Entrepreneurs in their Entrepreneurial Activities in Delta State. International Journal of Innovative Social \& Science Education Research 5(1):10-17

Fisher, D. (2011). Phishing, Social Networking Attacks on the rise. Threat post. Retrieved July 11, 2011 from world wide web:http:// threatpost. com/ enus/ blogsPhishing-socialnetworking-attack-rice-05/2011

Glenn D. I. (2009). Determining Sample Size, From . Retrieved on 2/22011

Green, A. (2011). Infographic: Social media for business statistics. Retrieved from http://www.creditdonkey.com/business-social-media.htm

Hanna, R., Rohm, A., \& Crittenden, V. L. (2011). We're all connected: The power of the social media ecosystem. Business horizons, 54(3), 265-273.

Hughes, M.E. (2016). Entrepreneurship in a Web 2.0 World: Factors influencing Intentions to Adopt Web 2.0 Social Media in US Entrepreneurial Activities. State University of New York at Albany.

Karr, D. (2015). 9 benefits of social media marketing. Preuzeto $\mathrm{s}$ htts://www. marketintechblog.com/b2b-social-media-benefits (17.9.2015.

Kim, K, Yoo-Lee, E. and Sim, S. J. (2011). Social media as information social: undergraduates use and evaluation behaviour. ASIST, October 9 - 13, New Orleans, USA.

Kirakosyan, K. (2014). The managerial view of social media usage in banking industry: case study for Romanian banking system. Proceedings of the International Management Conference, Faculty of Management, Academy of Economic Studies, Bucharest, Romania, 8(1), 225-241.

Lorenzo-Romero, C., Chiappa, G.D., \& Alarcon-del-Amo, M. (2013). The user's adoption and usage of social network sites: an empirical investigation in the context of Italy. In International Marketing Trends Conference. Paris, France.

Madiha Z. and WalidK. (2016) Causes of Tunisians SME Failure. Economics Publishers 2016.

Nasir, N.A.B.M., Nawi, N.B.C., Mamun, A.A., Fazal, S.A., \& Raston, N.B.A. (2017). Examining the issues influencing the depth of social media usage as a business platform among student entrepreneurs. Advanced Science Letters, 23(9), 8210-8217.

Oxnevad, S. (2013). Powerful Google Docs Features to Support the Collaborative Writing Process. Retrieved.

Seroka-Stolka, O., \& Tomski, P. (2014). Internet social media and international entrepreneurial intentions. In Proceedings of the Wei International Academic Conference.

Shen, J. (2008). User acceptance of social shopping sites: A research proposal. Pacific Asia Conference on Information Systems (PACIS) 2008 Proceedings. 
Sokoya, A. A, Onifade, F. N. and Alabi, A. O. (2012). Establishing connections and networking: the role of social media in agricultural research in Nigeria. Available at http://conference.ifla.org/ifla78. Retrieved August 2012.

Stern, B.B., Royne, M.B., Stafford, T.F., \& Bienstock, C.C. (2008). Consumer acceptance of online auctions: An extension and revision of the TAM. Psychology \& Marketing, 25(7), 619-636.

Ukpere, Slabbert, and Colastin L. (2014). A Relashionship Between SMEs and the Financial Success of modern African Enterprises.

Weber, L. (2009). Marketing to the social Web. Howe digital customers communities build your business. New Jersey: John Wiley and Sons.

Zahra, S. A. (2011). Doing research in the (new) Middle East: Sailing with the wind. The Academy of Management Perspectives, 25(4), 6-21. 